\title{
Boosting Their Stomachs': The Role of Social Grants in South Africa
}

\author{
Priscilla Gutura, Pius Tangwe Tanga \\ University of Fort Hare, South Africa \\ priscillagutura@gmail.com
}

\begin{abstract}
The findings of this paper emanates from a broader research that was conducted to examine the role of social grants on poor rural households in Ngqushwa Municipality in the Eastern Cape Province of South Africa. The study adopted a methodological triangulation approach in data collection and analysis. Five hundred (500) questionnaires were distributed among social grant beneficiaries who were selected using multi-stage sampling. These yielded quantitative results which were then complemented by qualitative results obtained from 25 in-depth interviews and 2 focus group discussions conducted with 16 participants. One of the objectives of the broader study was to explore the role of social grants in tackling the vulnerability of beneficiaries to hunger. The major findings of the study point to the fact that the greatest discretion of spending is on food. This has improved food accessibility and availability among beneficiaries and has most importantly reduced both child and adult hunger in households where social grants are injected. Social grants have no doubt reduced hunger and sufferings among beneficiaries. However with the economic downturn and escalating food prices, the nutritional value is lower and beneficiaries remain in poverty as they are not food secure.
\end{abstract}

Keywords: Food security, child hunger, adult hunger, social grants, nutrition

\section{Introduction}

The Human Science Research Council (2011) in their report noted that food insecurity has emerged as a global crisis following the global economic meltdown. According to Food and Agriculture Organization (FAO) (2010) out of more than 814 million people in developing countries who are undernourished, 204 million people live in countries of Sub-Saharan Africa, including South Africa. On another note, Baratz and Grisby (1971) list a catalogue of factors which do not describe people as poor but are elements which, if they are deprived of, will place them in circumstances that can render them poor. Among these elements is hunger. This explains why the first Millennium Developmental Goal is eradicating extreme poverty and hunger. There is a general recognition by the international community of the importance of managing food security as one of the measures to address the Goal Number One of the Millennium Development Goals (FAO, 2012). In most developing countries the poor spend over half their incomes just feeding themselves with difficulties (FA0, 2012). Despite of the acknowledgement of the reduction in the number of people who are undernourished, many are still suffering from chronic undernourishment which is still unacceptably high. According to De Klerk et al. (2004), despite this national status of being food secured, it has been estimated that about 1,5 million South African children are malnourished, with 14 million people prone to food insecurity, $43 \%$ of the households suffer from 'food poverty' (National Treasury, 2003). This is particularly true of people in South Africa who were born in a system where the majority of the people were deprived of education, proper employment and socio-economic opportunities which conspire to relegate them to chronic cycle of poverty (Makiwane and Kwizera, 2006).

Similarly, Altman, Hart and Jacobs (2009:349) noted that a large proportion of South African households are food insecure, and that it is currently not possible to monitor progress towards greater food security. Hendricks (2005) maintains that South Africa is nationally food secure but $73 \%$ of South African households experience food insecurity. Therefore, the eradication of hunger remains a major global problem that needs further attention (FA0, 2012). Nevertheless, the right to food security is enshrined in Article 27 of the Bill of Rights of the Constitution of the Republic of South Africa (1996). Article 27 states that every citizen has the right to have access to sufficient food and water (Republic of South Africa, 1996). The Reconstruction and Development programme (RDP) drafted in 1994 identified food security as a priority policy objective. As a result the government reprioritized public spending on the 
improvement of the food security conditions of historically disadvantaged people. The democratic South Africa was born amidst high hopes for the reduction of income poverty and inequality from their high levels under apartheid. It is noted that the current South African government is indebted to provide basic human service delivery to its citizens as required by the Constitution of the Republic of South Africa, 1996 (Act 108 of 1996). This constitution guarantees everyone a right to equality and the right of access to social security. In terms of section 27(1) of the constitution, everyone has a right of access to social security, including social assistance, if they are unable to support themselves and their dependents (Republic of South Africa, 1997). The state according to the constitution is compelled to take reasonable legislative and other measures within its available resources to achieve the progressive realisation of each of these rights.

The provision of social assistance has, historically, been seen as a core feature of the welfare system aimed at the prevention of poverty during the transition to a multi-racial democracy in South Africa. The present social assistance framework consists primarily of social grants that are targeted at the disabled, the elderly and children who were born on or after 31 December 1996, with over 16 million beneficiaries (SASSA, 2013). Indeed, the level of social spending in terms of social grants in South Africa is extremely high as compared to other developing countries and even other Western European countries. It is therefore clear that social grants in South Africa are sizeable and indeed impressive in comparison to both developed and developing countries. In addition to the impressive coverage of South Africa's social assistance system, the impact of social grants on household formation implies that the impact of social grants extends further than simply to those who qualify to receive them (Armstrong and Burger, 2009; Tanga and Tangwe, 2014). The grants system on its own has dislocated some of the people from their indigenous economic pursuits like agriculture (Ncube, Tanga \& Bhumira, Blessward, 2014. Therefore, the main aim of this paper is to examine the impact of social grants on reducing hunger among social grant beneficiaries.

\section{Literature Review}

While the impact of social protection programs varies according to their objectives, design and level of institutionalization, as well as the level of development of the countries where they are implemented, there is strong evidence that social protection initiatives can significantly contribute to reducing the prevalence and severity of poverty (Barrientos and Nino-Zarazua, 2010; Tanga and Gutura, 2013a); and in doing so ensure that those living in poverty enjoy at least minimum essential levels of some economic, social and cultural rights. According to ILO (2011) in Organization for Economic Co-operation and Development (OECD) countries, for example, it is estimated that levels of poverty and inequality are approximately half of those that might be expected in the absence of social protection. In Brazil, evidence suggests that its large-scale Bolsa Familia social transfers program has had a major impact on women's labour market participation. The participation rate of beneficiary women is $16 \%$ greater than for women in similar non-participating households. The program has also reduced the probability of employed women leaving their jobs by $8 \%$ (Veras et al., 2007). The program helps women in services such as preschools and day-care for their children, otherwise easing the time burdens placed on women, therefore offering women more opportunity to seek and continue employment (Social Research Center, 2008). Argentina's Jefes y Jefas de Hogar public works program has also increased the propensity of workers, particularly women, to participate in the labour force and to find a job in the formal sector (Devereux and Solomon, 2006).

Table 1: Poverty indicators using national poverty lines between Sep 2008 and Aug 2009

\begin{tabular}{lllc}
\hline Poverty line & $\begin{array}{l}\text { Poverty } \\
\text { headcount }\end{array}$ & $\begin{array}{l}\text { Poverty } \\
\text { Gap }\end{array}$ & $\begin{array}{c}\text { Severity of } \\
\text { poverty }\end{array}$ \\
\hline Food poverty line (R305) per capita per month & 26.3 & 8.5 & 3.8 \\
Lower-bound poverty line (R416) per capita per month & 38.9 & 15.0 & 7.5 \\
Upper-bound poverty line (R577) per capita per month & 52.3 & 23.6 & 13.3 \\
\hline
\end{tabular}

(Source: Statistics South Africa, 2012) 
South Africa has no official definition of poverty, nor any official measurements of poverty. The result of this is that various researchers and analysts use diverse measures, which makes inter-study comparison very difficult (Frye, 2008). Nevertheless, Gumede (2010) highlights that even though poverty appears to have declined in the recent past, it still remains high. Substantially, Statistics South Africa (2012) presented the poverty profile of South Africa using three poverty indicators, namely the poverty headcount, poverty gap and severity of poverty. The poverty headcount denotes the proportion of the population living below a poverty line, while the gap shows the mean distance of the poor from the poverty line. The severity of poverty is an indicator that gives a description of extreme poverty by giving greater weight to those further from the poverty line. The rand values that were attached to each line were, Food Poverty Line (R305); Lower-bound poverty line (R416) and Upper- bound poverty line (R577). Table 3.1 below indicates the poverty indicators using the national poverty lines between September 2008 and August 2009.

As the table indicates, during the period September 2008 to August 2009, approximately $26.3 \%$ of the population was living below the food poverty line; $38.9 \%$ below the lower bound poverty line and $52.3 \%$ below the upper bound poverty line. The black population is still worse in all the measures of human poverty index. The Southern Africa Labour and Development Research Unit (SALDRU) (2010) reported that $47 \%$ of South Africans lived below the poverty line, $56 \%$ of blacks lived in poverty compared to $2 \%$ of whites, using arbitrary income poverty line of R502 per capita. In addition, women were in worse situations in terms of poverty than men. Also rural areas continued to have high poverty. Even though some of the poverty indicators suggest welcome improvements in terms of poverty levels, it is clear that there are still millions of poor people who are exceedingly vulnerable and at risk. In the absence of other safety nets, access to social security can mean the difference between poverty and destitution for many people and households. South Africa suffers from high and increasing poverty levels and extreme inequality (Gutura and Tanga, 2014). The social security system (mainly social grants) is the government's chief initiative in tackling these problems. It aims to immediately reduce poverty among groups not expected to participate fully in the labour market thereby increasing investment in health, nutrition and education. Literature that has been reviewed regarding social security and its impact on food security, points to the realisation that cash transfers, for example improve food security by; improving food access and providing households with income to purchase food (Tanga and Gutura, 2013b); increasing spending on food by grant recipients (Fiszbein et al., 2008 and Gertler, 2005). Specifically in South Africa, Booysen and Van Der Berg (2005) found that income grant recipients used the social grant primarily to pay for food. Additionally, numerous other studies found positive impacts of social grants on food security (Adato and Basset, 2012 and Miller, Tsoka and Reichert, 2007). Notwithstanding these findings, questions still arise whether social grants in a country which is plagued by poverty and unemployment and, following the recent global economic crisis, by steep food and fuel prices, high-energy tariffs and increasing interest rates can boost food security in poor rural households where they are entirely depended on social grants.

\section{Methodology}

The area where the study was conducted is described in detail together with the research methodology employed.

Description of research area: The study was conducted in Ngqushwa Local Municipality (NLM) which is one of the eight municipalities that fall within the jurisdiction of the Amathole District, which is situated within the Eastern Cape Province of South Africa. It is bordered by the Great Fish River to the west and the Keiskamma River to the east. The southern boundary comprises part of the coastline of the Indian Ocean. According to Statistics South Africa (2011), it has 118 villages and is made up of 20757 households. Its geographical area accounts for $10 \%$ of the district. Statistics South Africa (2011) indicates that the estimated population of people staying in Ngqushwa Local Municipality is 90482 people. Of the total population, approximately $38 \%$ are 19 years or younger and $10 \%$ of the population are 65 years and older which means that $52 \%$ of the population are between the ages of 20 and 64 years. In terms of gender, $53 \%$ of the population is female and the remaining $47 \%$ is male. The municipal area does not display much racial diversity, with more than $99 \%$ of the inhabitants being African. The remaining $1 \%$ is comprised of coloured, white and Indian racial groups. In the municipality, $2.7 \%$ of households are 
headed by persons under the age of 20 years and $18.6 \%$ are headed by persons over the age of 64 years; however, $52 \%$ of households are headed by women.

The number of people living in poverty in the municipality has risen from $64.19 \%$ in 1996 to $80.29 \%$ in 2005. Unemployment figures in the municipality are very high and according to Ngqushwa Local Municipality (2012) are calculated at 78\% thus having the highest unemployment rate (more than $20 \%$ above the Eastern Cape average). The number of households earning less than R1500/month is estimated at $66.8 \%$ which is very high in comparison to the rest of the province. Household income levels in the area are generally low. According to the 2011 statistics $71 \%$ of the population earns less than R800 per month. Further, $19 \%$ of the population earn between R800 and R3200 per month. Only $3.9 \%$ of the population earns more than R3200 per month. Nevertheless in Ngqushwa Local Municipality only $23.5 \%$ of the population is employed. Consequently, this influences the dependence on social grants whereby there is a high dependence on social grants with $72.5 \%$ of households receiving grants. In order to answer the research questions in the study, a fieldwork approach in the form of mixing different research methods was adopted and this is called methodological triangulation. Thus, there was use of the combination of two diferrent qualitative data collection methods (in-depth interviews and focus group discussions) and one quantitative data collection method (questionnaires). The questionnaire method was selected as the first method of data collection because it was expected that it would produce varying amounts of important information and make possible the identification of notable issues for investigation during the ensuing interviews and for focus group discussions. Although the interviews and focus group discussions focused on a much narrower range of subjects, they provided the opportunity to explore in greater depth issues and concerns that could not be examined in detail in the questionnaire.

Furthermore, the population of the study referred to all beneficiaries of social security grants in Ngwushwa municipality. According to SASSA (2012), the total number of beneficiaries in this municipality amount to a total of 53, 847. Therefore in selecting a sample the study employed two sampling strategies namely multi-stage sampling and purposive sampling. Multi- stage sampling was used to select the sample that was used for the survey whereby beneficiaries were administered questionnaires. Multi- stage sampling was used in order to randomly select elements from each of the five major areas that were found in the municipality. This was so because the study's population of interest was massive. Using all the sample elements in the selected areas was going to be expennsive and unnecessary, therefore under these circumstances, multi-stage sampling became useful.Purposive sampling was used to select participants for in-depth interviews and focus group discussions. Hence, the study consisted of 3 sets of samples; the first one consisted of 500 beneficiaries who were administered survey questionnaires. The questionnaire had a lickert scale whereby the responses were to be given as strongly agree, agree, neutral, disagree or strongly disagree. The second set was made up of 25 beneficiaries who were interviewed using in-depth interview guides. The third sample was made up of 16 beneficiaries who were selected for the 2 focus group discussions.

\section{Findings}

It is widely acknowledged that social security programmes significantly redistribute income, which many contend a substantial contribution to the country's development. However, there is limited understanding of the dynamics of social grant recipients and their food security. Nevertheless, this paper sought to find out whether social grants were contributing to food security in the households. This section therefore provides the findings of the study.

Biographical information of participants: Females were in numerical preponderance over males; that is $56.0 \%$ were female and $44.0 \%$ were male. The majority, who were blacks, were $90.0 \%$ and $10.0 \%$ were coloureds. No White or Indian beneficiaries participated in the study. The total participants $(N=541)$, the highest number of participants was represented by single beneficiaries and they made up $42 \%$. The widows made up $16 \% ; 12 \%$ were cohabitating and the separated category $10 \%$. The findings further highlights that the least number of participants was found in the divorced category which was made up of $2 \%$ of the participants. The levels of educational qualifications in the study comprised of primary, secondary, matric and tertiary education. The participants were distributed in all these four levels. Those who were educated up to secondary level were represented by a substantial number that is $54 \%$. 
Compared to those falling in other levels of educational attainment, these were found to be in the majority. Following on them were those who had gone for some primary education; these constituted $16 \%$ of the beneficiaries. Fourteen percent of them mentioned that they had tertiary qualifications whilst the least number of participants had matriculated (12\%). The results signify that the majority of the respondents in the study were not employed thus constituted $92 \%$ whilst only $8 \%$ indicated that they were employed.

Types of social grants received: The results of the study indicated that there were six types of social grants that were being received by the participants. Figure 1 shows the distribution of participants according to each grant type. These grants are abbreviated as Old Age Grant (OAG), Disability Grant (DG), Child Support Grant (CSG), Foster Care Grant (FCG), War Veteran's Grant (WVG), Care Dependency Grant (CDG) and Grant in Aid (GIA).

Figure 1: Type of social grants received by the participants

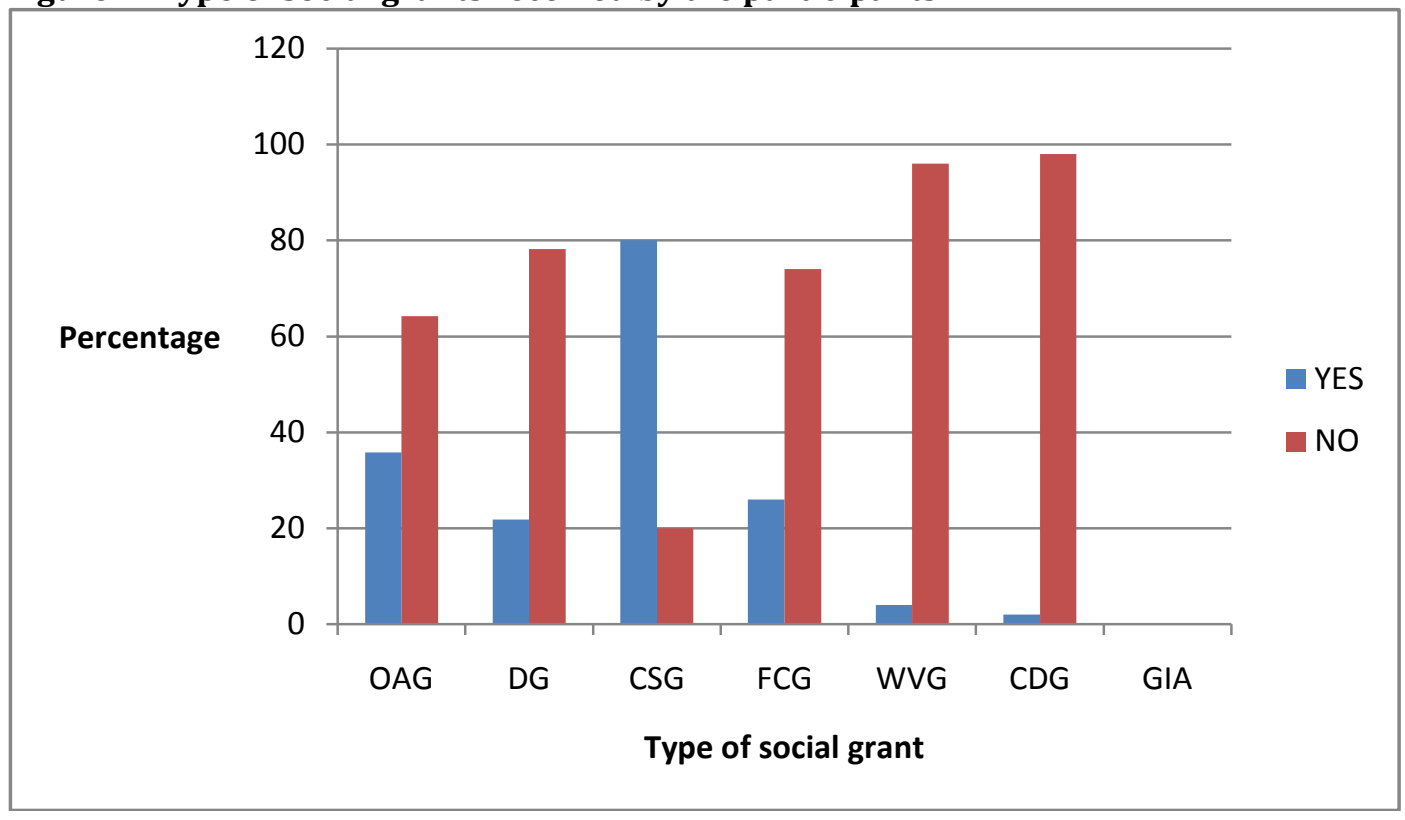

The figure above shows that $80 \%$ of the participants indicated that they were receiving the Child Support Grant followed by 35.8\% who were getting the Old Age Grant. Regarding the War Veterans Grant only 4\% revealed that they were receiving it and the least number $(2 \%)$ were receiving the Care Dependency Grant. Nevertheless, no respondent in the study was receiving the Grant in Aid.

Social grants buying food groceries: When the respondents in the quantitative study were asked to indicate whether they used the grants money to buy food groceries, they related similar opinions in food consumption despite racial lines or age groups simply because they all came from somewhat similar economic backgrounds and lived in the same community. Almost 32\% agreed; $30 \%$ strongly agreed and $28 \%$ remained neutral. However $10 \%$ of the respondents could not have the same opinion that they used the money to buy food groceries. These constituted $6 \%$ who disagreed and $4 \%$ who strongly disagreed. Similarly, the results from the interviews also indicated that the majority of the participants used the money from the grants to buy food groceries as well. Of all the 25 interviewees, 23 revealed that they buy food each time they received the social grants money. One 38 year old mother said: Food is what is important in my household, without food there is no happiness. Every time when I receive the money from the grants I combine it and use it to buy food among other things but I prioritize food. These children need to eat so that they can be healthy and have the energy to go to school and play with others. (Participant A)

However, contrary to this, two participants indicated that they did not use the money to buy food. A 28 year old single mother indicated that: Since I started receiving the Child Support Grant for my 3 year old 
daughter I have never used it to buy food. The money is not that much so usually I buy a pack of pampers and clothes for her since they are essential. Even though food is also important the money for maintenance from the father buys the food groceries. (Participant G). Additionally, during the focus group discussions, the participants discussed what they used the grants money for and they listed these things according to priority. The results showed that food was on top of the list. One of the participants in one of the groups said: I am happy that food came on top in the voting exercise. We want our households to be free of hunger. Our only hope is that the government will increase the grant so that we can do away with hunger among both children and adults in our homes. (Participant L). Nevertheless, using the money to buy food groceries varied across grant types. Table 2 shows the cross tabulation results in terms of frequencies and percentages of respondents according to each grant type they were receiving.

It is evident from Table 2 that the majority of the respondents who were receiving the Old Age Grant used the money mostly to buy food groceries. These were represented by $33.5 \%$ who agreed and $27.4 \%$ who strongly agreed. The Child Support Grant which was being received by 300 respondents in the study proved to have been widely used to buy food groceries since a vast majority of $36.7 \%$ strongly agreed to use the grant for that purpose. The table further reveals that among the respondents who were receiving the Foster Care Grant, 53.8\% agreed to use the grant mostly for buying food groceries. Regarding the gender of the respondents in terms of buying food groceries, the results of the study indicated that there were more females than males who strongly agreed that they used the money to buy food groceries.

Table 2: Cross tabulation of each social grant type and buying food groceries

\begin{tabular}{|c|c|c|c|c|c|c|}
\hline \multicolumn{7}{|c|}{ The grant's money mostly buy food groceries } \\
\hline Grant Type & $\begin{array}{l}\text { Strongly } \\
\text { Agree }\end{array}$ & Agree & Neutral & Disagree & $\begin{array}{l}\text { Strongly } \\
\text { disagree }\end{array}$ & Total \\
\hline \multirow[t]{2}{*}{ Old Age Grant } & 49 & 60 & 40 & 20 & 10 & 179 \\
\hline & $27.4 \%$ & $33.5 \%$ & $22.3 \%$ & $11.2 \%$ & $5.6 \%$ & $100.0 \%$ \\
\hline \multirow[t]{2}{*}{ Disability Grant } & 29 & 30 & 40 & 10 & 0 & 109 \\
\hline & $29.6 \%$ & $27.5 \%$ & $36.7 \%$ & $9.2 \%$ & $0.0 \%$ & $100.0 \%$ \\
\hline \multirow[t]{2}{*}{ Child Support Grant } & 110 & 90 & 80 & 20 & 0 & 300 \\
\hline & $36.7 \%$ & $30.0 \%$ & $26.7 \%$ & $6.7 \%$ & $0.0 \%$ & $100 \%$ \\
\hline \multirow[t]{2}{*}{ Foster Care Grant } & 30 & 70 & 20 & 0 & 10 & 130 \\
\hline & $23.1 \%$ & $53.8 \%$ & $15.4 \%$ & $0.0 \%$ & $7.7 \%$ & $100.0 \%$ \\
\hline \multirow{2}{*}{ War Veterans Grant } & 0 & 20 & 0 & 0 & 0 & 20 \\
\hline & $0.0 \%$ & $100.0 \%$ & $0.0 \%$ & $0.0 \%$ & $0.0 \%$ & $100.0 \%$ \\
\hline Dependency & 0 & 10 & 0 & 0 & 0 & 10 \\
\hline Grant & $0.0 \%$ & $100.0 \%$ & $0.0 \%$ & $0.0 \%$ & $0.0 \%$ & $100.0 \%$ \\
\hline
\end{tabular}

Table 3: Cross Tabulation on gender and buying of food groceries

\begin{tabular}{|c|c|c|c|c|c|c|}
\hline \multicolumn{7}{|c|}{ The grants' money mostly buy food groceries } \\
\hline Gender & $\begin{array}{l}\text { Strongly } \\
\text { Agree }\end{array}$ & Agree & Neutral & Disagree & $\begin{array}{l}\text { Strongly } \\
\text { Disagree }\end{array}$ & Total \\
\hline \multirow[t]{2}{*}{ Female } & 100 & 110 & 50 & 15 & 5 & 280 \\
\hline & $35.7 \%$ & $39.3 \%$ & $17.6 \%$ & $5.4 \%$ & $1.8 \%$ & $100.0 \%$ \\
\hline \multirow[t]{2}{*}{ Male } & 50 & 50 & 80 & 30 & 10 & 220 \\
\hline & $22.7 \%$ & $22.7 \%$ & $36.4 \%$ & $13.7 \%$ & $4.5 \%$ & $100.0 \%$ \\
\hline
\end{tabular}

As Table 3 indicates, $39.3 \%$ of the female beneficiaries agreed that they used the money mostly to buy food groceries as compared to only $22.7 \%$ of the male beneficiaries who also agreed. However a larger percentage (13.7\%) of males disagreed to buying of food groceries whilst only $5.4 \%$ of females disagreed. Furthermore, in the questionnaire the respondents were questioned on the type of food they bought with the grants money. Figure 2 illustrates the responses given by the respondents in the study. 
Fig 2: Type of food bought with the social grants

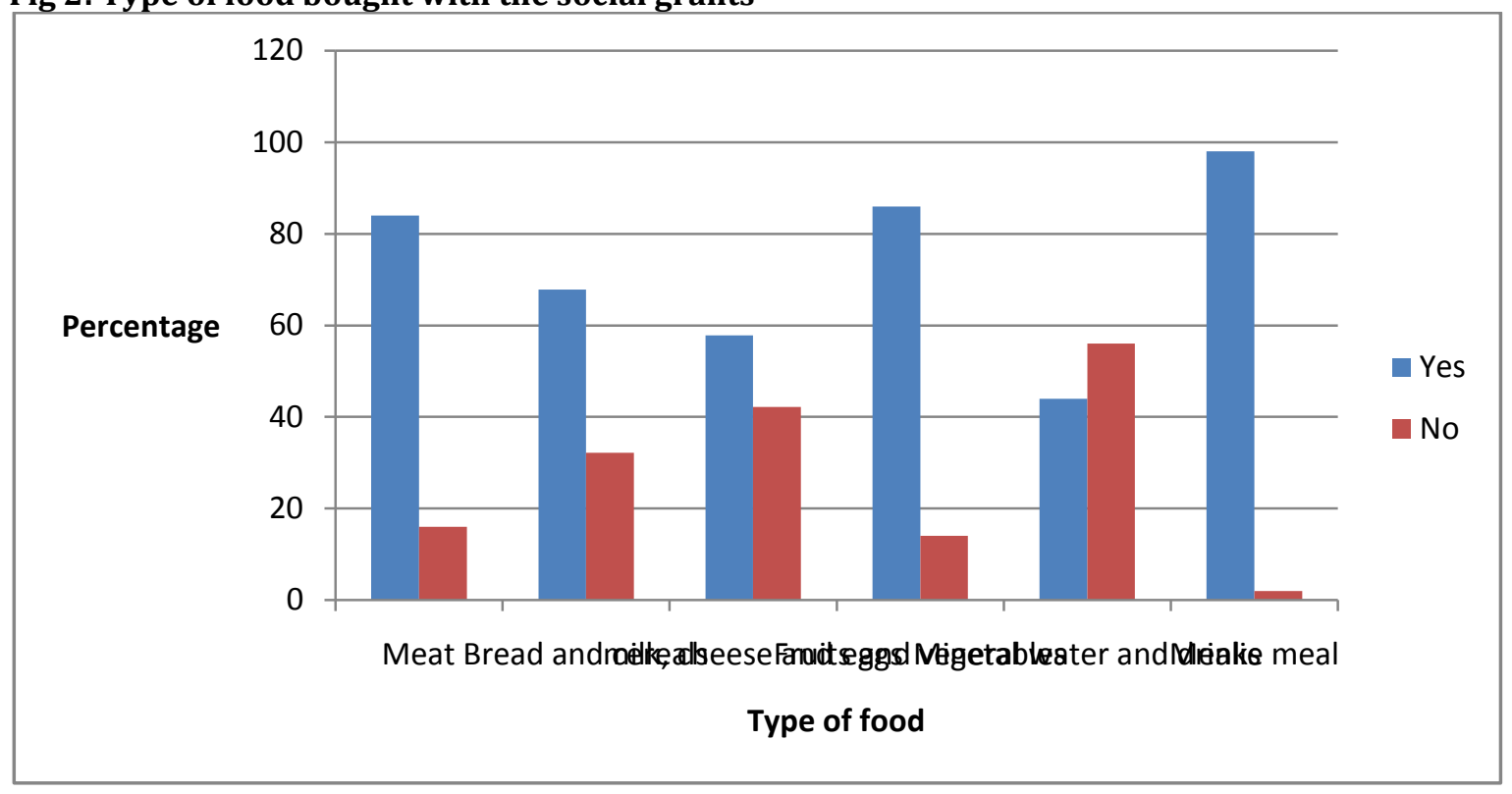

As indicated in Fig 2, the highest number of respondents mentioned that they used the grants money mostly to buy mealie-meal [maize meal]. These constituted $98 \%$ of the respondents as compared to $2 \%$ who said that they did not use the money for that. Additionally, the table shows that $86 \%$ stated that they used the money to buy fruits and vegetables, $84 \%$ bought meat, and $68 \%$ also mentioned that they used the money to buy bread and cereals. The least type of food that the beneficiaries bought using the grants money was mineral water and drinks.

The type of people that the social grants buy food for in households: A question was posed to the respondents regarding the type of people that they were buying the food for using the social grants. The results point out that the majority of the respondents (46\%) disagreed that the money bought food only for children and 10\% strongly disagreed. On the other hand, $12 \%$ agreed and $8 \%$ strongly agreed. Nevertheless, in terms of buying food for adults only, the highest number of respondents (46\%) disagreed with $16 \%$ more who strongly disagreed. However, $14 \%$ agreed that they bought food for adults only with the other $2 \%$ strongly agreeing to that. A total number of $22 \%$ of the respondents remained neutral. It was further investigated whether the respondents used the grants money to buy food for the entire household. As Fig 3 illustrates, not all respondents bought food for the entire household. The figure highlights the percentages of the responses given.

Fig 3: Social Grants used to buy food for the entire household

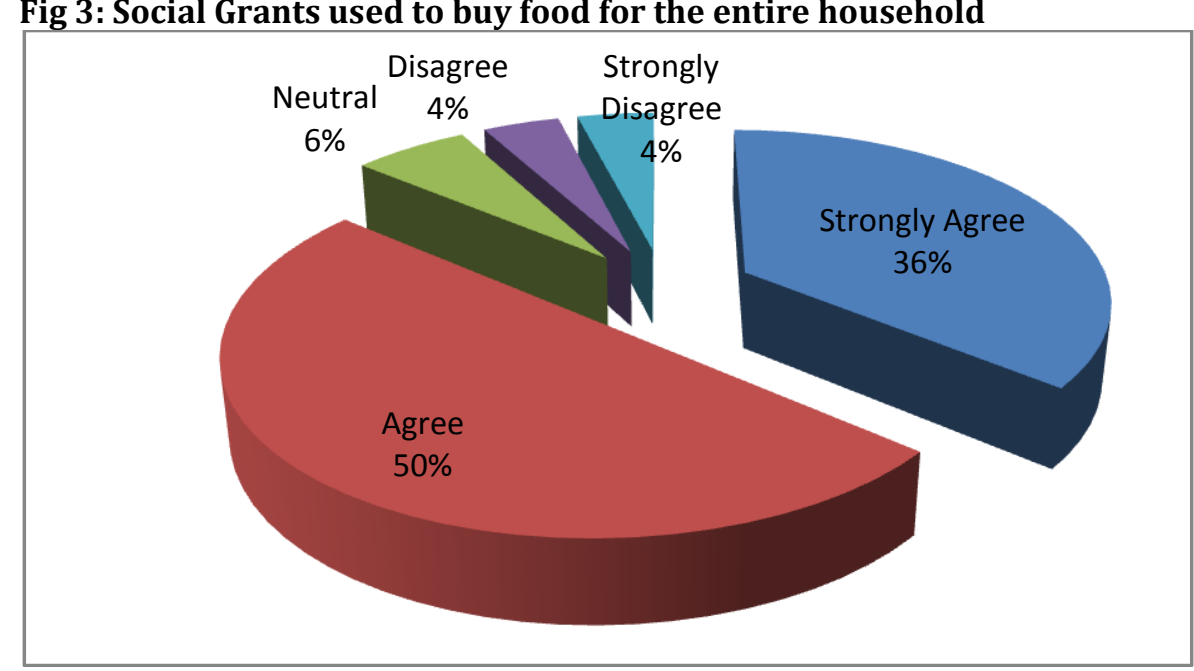


The results show that the majority of the respondents (86\%) mentioned that they used the money to buy food for the entire household. It can be seen from Fig 3 that 50\% agreed and 36\% strongly agreed. The other respondents $(8 \%)$ declined that they used the money to buy food for the entire household. Additionally, the qualitative results supported the quantitative results in that most of the participants who were interviewed highlighted that they bought the food for the entire households. Among the 25 beneficiaries interviewed, 17 highlighted that indeed they bought the food for the entire household using the grant's money. Notably, a 65 year old grandfather said: My wife takes care of all of us here especially on the kitchen side. When the grant comes at the end of the month I just give the money to my wife to buy food that will be enough for everyone who stays in my home. We eat together as a family. Since we do not get money from anywhere else we just use that money to buy groceries. (Participant J)

On the contrary, eight participants said that they bought food for the children only using the grant's money thus excluding the adults. These were mostly Child Support Grant beneficiaries. One 30 year old woman who was receiving the Child Support Grant mentioned that: I use the grant's money to buy food for my child only. My child is 4 years old and she needs a good diet and nutritious food so that she can grow well. This means that I dedicate the money to cater for her needs only therefore I do not use the money for any of my personal or anyone's needs but hers. (Participant $\mathrm{K}$ )

Hunger situation before and after social grants receipt: Still, from the data collected through the questionnaires, it became clear that, in general, before the beneficiaries started to receive social grants there were children in their households who went to bed hungry. Most of the respondents making up $50 \%$ mentioned that undeniably they had children who went to bed hungry. Of the $50 \%, 20 \%$ strongly agreed and $30 \%$ agreed. On the contrary the least number of respondents $(2 \%)$ strongly disagreed that they had children who went to bed hungry and $12 \%$ disagreed. In order to understand the situation after the receipt of social grants, the beneficiaries were asked to indicate the level of child hunger when they started receiving the grants. Therefore, cross tabulation was conducted and Table 4 shows the results on each grant type and children going to bed hungry after the start of receiving the grant.

Table 4: Cross tabulation on child hunger after beneficiaries started to receive grants according to each grant type

\begin{tabular}{lllllll}
\hline \multirow{2}{*}{$\begin{array}{l}\text { When I started receiving social grants there were children who went to bed hungry } \\
\text { Type of grant }\end{array}$} & $\begin{array}{l}\text { Strongly } \\
\text { Agree }\end{array}$ & Agree & Neutral & Disagree & $\begin{array}{c}\text { Strongly } \\
\text { Disagree }\end{array}$ & Total \\
\hline Old Age Grant & 30 & 20 & 40 & 70 & 19 & 179 \\
& $16.8 \%$ & $11.2 \%$ & $22.3 \%$ & $39.1 \%$ & $10.6 \%$ & $100.0 \%$ \\
Disability Grant & 20 & 0 & 20 & 60 & 9 & 109 \\
& $18.3 \%$ & $0.0 \%$ & $18.3 \%$ & $55.0 \%$ & $8.3 \%$ & $100.0 \%$ \\
Child Support Grant & 30 & 40 & 110 & 91 & 29 & 300 \\
& $10.0 \%$ & $13.3 \%$ & $36.7 \%$ & $30.3 \%$ & $9.7 \%$ & $100.0 \%$ \\
Foster Care Grant & 10 & 0 & 70 & 50 & 0 & 130 \\
& $7.7 \%$ & $0.0 \%$ & $53.8 \%$ & $38.5 \%$ & $0.0 \%$ & $100.0 \%$ \\
War Veteran's Grant & 0 & 0 & 0 & 20 & 0 & 20 \\
& $0.0 \%$ & $0.0 \%$ & $0.0 \%$ & $100.0 \%$ & $0.0 \%$ & $100.0 \%$ \\
Care Dependency Grant & 0 & 0 & 0 & 10 & 0 & 10 \\
& $0.0 \%$ & $0.0 \%$ & $0.0 \%$ & $100.0 \%$ & $0.0 \%$ & $100.0 \%$ \\
\hline
\end{tabular}

As the table shows, all the 20 respondents (100\%) that were receiving the War Veteran's grant disagreed with the statement that there were children who went to bed hungry when they started receiving the grant. In addition, the Care Dependency Grant beneficiaries had a $100.0 \%$ of the total respondents in that category that had no children who went to bed hungry. The respondents who were receiving the Disability Grant had their majority attesting to the fact that when they also started to receive the grant no children went to bed hungry. These were made up of $55.0 \%$ who disagreed and $8.3 \%$ who strongly disagreed making a total of $63.3 \%$. Nevertheless, $18.3 \%$ strongly agreed. Following, the majority of the respondents (49.7\%) who were receiving the Old Age Grant mentioned that there were no children who went to bed hungry when they started to receive the grant. These respondents were represented by 
$39.1 \%$ and $10.6 \%$ who disagreed and strongly disagreed respectively. On the other hand $16.8 \%$ strongly agreed that there were children who went to bed hungry. The lingering $22.3 \%$ of the respondents remained neutral. Furthermore, as Table 4 illustrates, among the Child Support Grant respondents, $(13.3 \%)$ agreed whilst $10.0 \%$ respondents strongly agreed that even when they were receiving the grant child hunger transpired. The respondents who were receiving the Foster Care Grant had $38.5 \%$ of the respondents disagreeing that there were children who went to bed hungry. The majority $53.8 \%$ were neutral. The results illustrated in the table show that most of the types of grants were distributed at all levels of child hunger among the respondents in the households. One of the hypotheses of the study read $\mathrm{H}_{0}$ : Social grants do not reduce child hunger in beneficiaries' households.

$\mathrm{H}_{1}$ : Social grants reduce child hunger in beneficiaries' households.

All the grant types thereof were tested to see the significance. Table 5 shows the chi-square results for each grant type.

Table 5: Chi-Square tests of each grant type and child hunger

\begin{tabular}{llll}
\hline Type of grant & Value & df & Asymp.Sig \\
\hline Old age Grant & 40.930 & 4 & .000 \\
Disability grant & 55.820 & 4 & .000 \\
Child Support Grant & 71.930 & 4 & .000 \\
Foster Care Grant & 55.159 & 4 & .000 \\
\hline
\end{tabular}

As indicated in Table 5, generally all the grant types had a significance value that was greater than 05 . Therefore the null hypothesis is rejected. This means that there is statistical significance in receiving any type of grant and reducing the vulnerability to child hunger. As shown in the table, the Chi-Square analysis gave the following results: Old Age Grant as the first independent variable; $\mathrm{X}^{2}=40.930, \mathrm{df}=4, \mathrm{p}=$ .000 . From these results because $.000<.05$, this represents a statistical significance between the two variables. This means that there is a statistical significance in receiving the Old Age Grant and reducing vulnerability to child hunger. The table further shows that using a chi-square test of independence, there was a significant interaction between the other social grant types. In the multiple linear regression analysis that was performed involving all the four grant types as independent variables and child hunger as the dependent variable, the results are illustrated in Table 6.

Table 6: Multiple Linear Regression analysis results for social grants in reducing child hunger.

\begin{tabular}{llll}
\hline Variable & B coefficient & Standard Error & T-value \\
\hline (Constant) & 0.929 & 0.100 & $9.281^{*}$ \\
Old Age Grant & 0.473 & 0.080 & $3.337^{*}$ \\
Disability Grant & 0.387 & 0.250 & 1.043 \\
Child Support Grant & 0.482 & 0.100 & $4.832^{*}$ \\
Foster Care Grant & 0.395 & 0.083 & $2.155^{*}$ \\
\hline
\end{tabular}

As indicated in Table 6, the $t$-statistics suggests that the constant $t=9.281$, Old Age Grant with $t=3.337$, Child Support Grant with $t=4.832$ and Foster Care Grant with $t=2.155$ are actually significant in reducing child hunger. Furthermore, the respondents were asked if there was any case in their households whereby there were adults who went to bed without eating any food before they started to receive social grants. The results indicate that $38 \%$ were neutral, $38 \%$ agreed and $8 \%$ strongly agreed. Only $2 \%$ of the respondents strongly disagreed and $14 \%$ disagreed. When they were asked whether there were any adults who went to bed hungry after starting to receive the social grants, a large number of respondents (38\%) disagreed. A further $14.2 \%$ strongly disagreed, $35.8 \%$ were neutral, $6 \%$ strongly agreed and also another $6 \%$ agreed. The results of the study further showed the relationship between each grant type and adult hunger. The cross tabulation results are shown in Table 7. 
Table 7: Cross tabulation of each social grant type and adult hunger

\begin{tabular}{lllllll}
\hline $\begin{array}{l}\text { Adult hunger } \\
\text { Grant Type }\end{array}$ & $\begin{array}{l}\text { Strongly } \\
\text { Agree }\end{array}$ & Agree & Neutral & Disagree & $\begin{array}{l}\text { Strongly } \\
\text { disagree }\end{array}$ & Total \\
\hline Old Age Grant & 20 & 10 & 59 & 70 & 20 & 179 \\
& $11.2 \%$ & $5.6 \%$ & $33.0 \%$ & $39.1 \%$ & $11.2 \%$ & $100.0 \%$ \\
Disability Grant & 10 & 0 & 39 & 50 & 10 & 109 \\
& $9.2 \%$ & $0.0 \%$ & $35.8 \%$ & $45.9 \%$ & $9.2 \%$ & $100.0 \%$ \\
Child Support Grant & 30 & 20 & 119 & 80 & 51 & 300 \\
& $10.0 \%$ & $6.7 \%$ & $39.7 \%$ & $26.7 \%$ & $17.0 \%$ & $100 \%$ \\
Foster Care Grant & 0 & 0 & 70 & 40 & 20 & 130 \\
& $0.0 \%$ & $0.0 \%$ & $53.8 \%$ & $30.8 \%$ & $15.4 \%$ & $100.0 \%$ \\
War Veterans Grant & 3 & 4 & 6 & 5 & 2 & 20 \\
& $15.0 \%$ & $20.0 \%$ & $30.0 \%$ & $25.0 \%$ & $10.0 \%$ & $100.0 \%$ \\
Care & 2 & 1 & 3 & 4 & 0 & 10 \\
Grant & $20.0 \%$ & $10.0 \%$ & $30.0 \%$ & $40.0 \%$ & $0.0 \%$ & $100.0 \%$ \\
\hline
\end{tabular}

The majority of the respondents who disagreed that there were adults who went to bed hungry came from the War Veteran's Grant that had all the 20 respondents $(100 \%)$ attesting to that. The table suggests that these were followed by the $45.9 \%$ who were receiving the Disability Grant who disagreed. Those that were receiving the Old Age Grant, 39.1\% disagreed, $11.2 \%$ strongly disagreed, and 33.0\% remained neutral. On the other hand there were some respondents who mentioned that indeed there were adults who went to bed hungry. These were distributed as $11.2 \%$ and $5.6 \%$ who strongly agreed and agreed respectively. When looking at the child grants, the respondents who indicated that they were receiving the Child Support Grant had a majority (39.7\%) who remained neutral, 20.7\% disagreed and $17.0 \%$ strongly disagreed. Moreover, in the case of Foster Care Grant 53.8\% remained neutral, 30.8\% disagreed whilst the remaining 15.4\% strongly disagreed. It can be seen from the results in Table 6 that adult hunger is distributed at all types of social grants. There was another hypothesis in the study which read: $\mathrm{H}_{0}$ : Social grants do not reduce adult hunger in beneficiaries' households.

$\mathrm{H}_{1}$ : Social grants reduce adult hunger in beneficiaries' households.

All the grant types thereof were tested to see the significance. Table 8 shows the chi-square results for each grant type.

Table 8: Chi-Square tests of each grant type and adult hunger

\begin{tabular}{llll}
\hline Grant Type & Value & df & Asymp.Sig \\
\hline Old age Grant & 65.032 & 4 & .005 \\
Disability grant & 75.456 & 4 & .004 \\
Child Support Grant & 53.179 & 4 & .000 \\
Foster Care Grant & 59.653 & 4 & .000 \\
War Veterans Grant & 73.991 & 4 & .000 \\
Care Dependency Grant & 78.299 & 4 & .001 \\
\hline
\end{tabular}

As indicated in Table 8, generally all the grant types had a significance value that was greater than .05 . As shown in the table, the Chi-Square analysis gave some of the following results:

- Old Age Grant: $\mathrm{X}^{2}=65.032, \mathrm{df}=4$ and $\mathrm{p} \leq 0.05$.

- Disability Grant: $X^{2}=75.456, \mathrm{df}=4$ and $\mathrm{p} \leq 0.04$.

- Child Support Grant: $\mathrm{X}^{2}=53.179, \mathrm{df}=4$ and $\mathrm{p} \leq 0.00$.

This means that there is statistical significance in receiving any type of grant and vulnerability to adult hunger. Therefore the null hypothesis is rejected. The qualitative results show that when the interviewees were asked to explain their situation before and after the receipt of social grants in terms of hunger many participants (18) indicated that there had been some changes in their lives. However a small number (seven) showed concern indicating that the grant was not enough. Among those who aired out positive outcomes, one participant said: Since I started to receive the Child Support Grant for my children, I can pay school fees on time, buy those uniforms and stationery. Before my kids would be sent away from 
school because I was failing to pay school fees. My neighbours would laugh at my children's uniforms because they were torn. (Participant I)

One 55 year old woman mentioned that: I just started to receive this Old Age Grant for old people like me who can't do anything and already I can see that things are looking up for the better. There is food always in the house. (Participant A)

Contrary to the views mentioned by some, one participant showed concern with the little if non positive impact that the grant she was receiving was making. She argued that: I do not see the difference in receiving this grant or not because the money is too little and I cannot buy food for everyone in the house. The food runs out before the month ends and we end up going to bed hungry. I have been staying in this shack my whole life so nothing has changed. (Participant G)

Additionally, during the interviews that were conducted the majority of the participants (20) highlighted that the social grant they were receiving made an impact in terms of food security in their households. As one 48 year old woman who was not employed and had never been employed in her life indicated that: To say that the grant that I am getting is not contributing to the food that I put on the table is being ungrateful. Look at me; I have no certificate, no experience who would employ me. I have many orphans here in my care but my children are not going to bed hungry. So yes the grant is contributing to food security especially in my household. (Participant B)

Interestingly, during one of the focus group discussions the issue was debated upon and one participant highlighted that: My point still stands, social grants are relieving suffering in our communities. It's very rare to find a household that has got individuals who are receiving social grants and people are going to bed hungry. Look at the way Spar (a local supermarket) gets full each and every month end. People are buying food with that money hence there is food security. (Participant C)

Discussion: The results of the study highlight that spending in the households focused more on basics like food. This means that all social grants were significantly and positively associated with a greater share of household expenditure on food. This is in line with Gertler (2005) and Fiszbein et al. (2008) who highlight that about $60-70 \%$ of the cash transfers to households are spent on food. The results of the study have shown that indeed social grants have managed to allow beneficiaries to buy food in their households. Food is typically the largest category of expenditure for the poor; comparative studies between Child Support Grant recipients and matched households that have Child Support Grant eligibility but non-receiving individuals clearly show differential levels of food expenditure (Delany et al., 2008). Additionally, many studies have confirmed the impact of social grants on food expenditure of social grant beneficiaries (Van der Berg, Siebrits and Lekezwa, 2010). Even Booysen and Van der Berg (2005) explored the influence of income grant on food expenditure and they found out that there were similar trends in South Africa where beneficiaries used the social grant to pay for food.

Furthermore, the study discovered significant variations on all social grant types in terms of buying food using the money. It was indicated that the money from the major grants which are OAG, DG, and WVG is not used for the target group of people in the household in terms of buying food but for the entire household. In many developing countries especially in Africa, large extended families often live together. Shared housing may suggest the sharing of other resources, most notably money. According to Demba (2012), Tanga and Gutura (2013a,b), Tanga and Tangwe (2014) the benefits of pensions are found to be distributed more broadly to all in the household as the majority of poor households in South Africa live in intergenerational households. In particular, the Old Age Grant not only helps the recipient who is the grandmother or grandfather in the household, but it also benefits the children of the recipients who are unemployed, the grandchildren orphaned through HIV and AIDS, as well as the abandoned children left for the grandmothers to take care of. Barrientos and Lloyd-Sherlock (2011), in their research in Brazil, found that social pensions were able to support entire families. Nevertheless, the results of the study also suggest that the Child Support Grant buys food for children only even though a smaller percentage argued that they also bought food for the adults. This may be the result of the fact that the Child Support Grant is characterised by the current smaller value of R290 (SASSA, 2013) which will not afford to buy food for the entire household thereof. 
Social transfers are strongly associated with improvements in the quantity and quality of food consumption, which improves nutritional status and lowers documented levels of morbidity and stunting (Gertler and Boyce, 2001; Devereux, 2001). These effects are evident in relation to both the Old Age Grant (Ardington and Lund, 1995; Case and Deaton, 1998; Lund, 2002), and the Child Support Grant (Delany et al, 2008). The study has noted that there is a strong relationship between social security and the nutrition of household members. The increase in spending on food is therefore associated with better nutritional as indicated in the study by the type of food being bought by the beneficiaries. The study revealed that most of the beneficiaries buy food like fruits and vegetables, maize- meal, meat that and these add nutritional value. Therefore important insights have been provided on the positive significant impact of social security grants on food share expenditures, implying improvements in household nutrition. However, it does not necessarily mean that the nutritional value in these households is high as the beneficiaries are only affording the basic necessities in quantity not in quality. The improvements in nutritional status associated with social grant receipt are a significant developmental outcome. Inadequate nourishment, particularly in preschool children, leads to lower levels of physical growth and impaired cognitive development. In Zimbabwe, children affected by the 1982 and 1984 droughts lost an average of over two centimeters of height, 0.4 grades of schooling and experienced a school delay of almost four months (Hoddinott and Kensey, 2001).

While statistical analysis cannot prove causation, the empirical results are consistent with the hypothesis that social grants reduce vulnerability of beneficiaries to hunger. Against this background, it is safe to conclude that the results of the study, at the level of the children, adults and households, complement the plentiful evidence that shows that cash transfers improve food availability. Typically, a large proportion of the cash transfer is spent on food: the evaluation of Malawi's Food and Cash Transfers showed that $75.5 \%$ of the transfer was typically spent on groceries (Devereux and Solomon, 2006). In Lesotho, the number of old age pensioners reporting that they never went hungry increased from $19 \%$ before the pension to $48 \%$ after it was introduced (Croome and Nyanguru, 2007). As well as increasing the volume of food available, cash transfers lead to an increase in the variety of foods consumed within the household: in Zambia 12\% more households consumed proteins everyday and 35\% consumed oil everyday if they received a transfer, compared with those households that did not (MCDSS/GTZ, 2007). As pointed out by the Department of Social Development (2009), the prevalence rate of hunger is highest in one of South Africa's poorest provinces with nearly one in three households in the Eastern Cape experiencing hunger. Still, the participants shared different opinions about whether they were food secure or not. Some believed that by having something to eat they were food secure. However, others strongly disagreed to being food secure.

Moreso, as the results of this study indicate social grants are effective in addressing this problem of hunger. The results of the study presented above are conclusive in sometimes unexpected ways that by reducing hunger there is poverty reduction. However, the magnitude of these impacts of course depends critically on the poverty line by which the impacts of the reforms are measured. But, according to Tanga (2007) and Siebrits, Armstrong and Lekezwa (2008), South Africa's system of social security successfully reduces poverty, regardless of which methodology is used to quantify the impact measure or identify the poverty line. Nevertheless, the quantitative measure of poverty reduction is sensitive to methodological choices. Thus, we may not conclude safely that poverty has indeed declined or that social grants played a major role in this regard.

\section{Conclusion}

Albeit the results of the study may highlight that the social grant beneficiaries are affording to buy food using the money, therefore fighting hunger, the question still stands if they are being food secure. Looking at the escalating food prices, particularly of wheat and maize which are the staple diets of the poor in South Africa, there is pretence of severe problems for the rural poor as most of them are landless and have become net buyers of food. Regarding the information provided by the Food and Agricultural Organisation (FAO) (2009) and also (Heady and Fan, 2008), it is highlighted that food prices will continue to increase steadily over the next decade even if there are some fluctuations and the occasional drop in prices. As a result, as seen in the study, poor households will increasingly be forced to allocate a greater proportion of their grant money expenditure to food. This may also result in diets becoming less diverse 
and lower in quality. In a nutshell, although social grants have played a vital role in improving food security among poor households, the current high levels are arguably not sustainable.

\section{References}

Adato, M. \& Bassett, L. (2012). Social Protection and Cash Transfers to strengthen families affected by HIV/AIDS. Washington D.C: International Food Policy Research Institute.

Altman, M., Hart, T. \& Jacobs, P. (2009). Household food security status in South Africa. Agrekon, 48(4), 36- 49.

Ardington, E. \& Lund, F. (1995). Pensions and development. Social security as complementary to programs of reconstruction and development. Development Southern Africa, 3(12), 557-578.

Armstrong, P. \& Burger, C. (2009). Poverty, Inequality and the Role of Social Grants: An Analysis using Decomposition Techniques. Working Papers 15/2009, Stellenbosch: Stellenbosch University, Department of Economics.

Baratz, M. S. \& Grigsby, W. (1971). Thoughts of poverty and its elimination. Journal of Social Policy, 1(2), 119-134.

Barrientos, E. \& Llyod-Sherlock, P. (2011). Non-contributory pensions and poverty prevention: A comparative study of Brazil and South Africa. London: IDPM and Help Age International.

Barrientos, A. \& Nino-Zarazua, M. (2010). The Effects of non-contributory social transfers in developing countries: a Compendium. Manchester: Brooks World Poverty Institute.

Booysen, F. \& Van Der Berg, S. (2005). The role of social grants in mitigating the socio-economic impact of HIV/AIDS in two free communities. South African Journal of Economics, 4(73), 545-563.

Case, A. \& Deaton, A. (1998). Large cash transfers to the elderly in South Africa. NBER Working paper series, W5572 (7), 23-24.

Croome, D. \& Nyanguru, A. (2007). The Impact of the Old Age Pension on Hunger and Vulnerability in a Mountain Area of Lesotho. Report written for the Regional Evidence Building Agenda (REBA) of the Regional Hunger and Vulnerability Program (RHVP). Maseru: National University of Lesotho.

De Klerk, M., Drimie, S., Aliber, M., Mini, S., Mokoena, R., Randela, R., Modiselle, S., Vogel, C., De Swardt, C. \& Kirsten, J. (2004). Food security in South Africa: key policy issues for the medium term. Position paper for the National Treasury. Pretoria: National Treasury.

Delany, A., Ismail, Z., Graham, L. \& Ramkissoon, Y. (2008). Review of the Child Support Grant: Uses, Implementation and Obstacles. Johannesburg: Community Agency for Social Enquiry.

Demba, J. J. (2012). Overcoming poverty in old age: Social security provision in Lesotho, South Africa and Zimbabwe. International Social Work, 5, 1-12.

Department of Social Development. (2009). Progress Report. [Online] Available: http://www.socdev.gov.za/Documents/2009/April/progr.PDF (February 12, 2013).

Devereux, S. (2001). Social Protection in Namibia and South Africa. Sussex: Institute for Development Studies.

Devereux, S. \& Solomon, C. (2006). Employment Creation Programmes: The international Experience, Issues in Employment and Poverty. Discussion Paper No. 24. Geneva: Economic and Labour Market Analysis Department, International Labour Office (ILO).

Fiszbein, A., Shaby, N., Ferreira, M. G., Kelleher, M., Olinto, P. \& Skoufias, E. (2008). Conditional Cash Transfers for Attacking Present and Future Poverty. Development Research Group. The World Bank, Number 2597. December [Online] Available: http://ideas.repec.org/s/wbk/wbpubs.html (October 13, 2012).

Food and Agricultural Organization (FAO). (2009). The state of agricultural commodity markets. Rome: Food and Agricultural Organization of the United Nations.

Food and Agricultural Organization of the United Nations (FAO). (2010). Food insecurity in the world: addressing food insecurity in protracted crises. Food and Agricultural Organization of the United Nations, Rome. [Online] Available: http://www.fao.org/docrep/013/i1683e/i1683e (November 13, 2013).

FAO. (2012). The State of Food Insecurity in the world: Economic growth is necessary but not sufficient to accelerate the reduction of hunger and malnutrition. Rome: FAO.

Frye, I. (2008). Poverty, Social Security and Civil Security in South Africa: Triangulation transformation. Stuttgart: Studies in poverty and Inequality Institute. 
Gertler, P. (2005). The impact of conditional cash transfers on human development outcomes: A review of evidence from Progress in Mexico and some implications for policy debates in South and Southern Africa. Southern African Regional Poverty Network. Pretoria. [Online] Available: http://www.sarpn.org.za/documents/d0001109/p1224SARPNGertlerjan2005 (June13, 2012).

Gertler, P. \& Boyce, S. (2001). An Experiment in Incentive-Based Welfare: The Impact of Progress on Health in Mexico. Mimeo: University of California-Berkeley. [Online] Available: www.faculty.haas.berkeley.edu/gertler/working.../PROGRESA\%204-01.pdf (June 12, 2013).

Gumede, V. (2010). Poverty, Inequality and Human Development in a post-apartheid South Africa. Conference paper presented at Overcoming inequality and structural poverty in South Africa: Towards inclusive growth and development. Johannesburg, 20-22 September.

Gutura, P. \& Tanga, P. T. (2014). Social grants and the intended consequences: Is South Africa there yet? Mediterranean Journal of Social Sciences, 5(2), 659-669.

Heady, D. \& Fan, S. (2008). Anatomy of a crisis: the causes and consequences of surging food prices. IFPRI Discussion Paper 00831 (December). Washington, DC: International Food Policy Institute.

Hendricks, S. (2005). The Challenges facing Empirical Estimation of food insecurity in South Africa. Development Southern Africa, 22(1), 1- 21.

Hoddinott, J. \& Kensey, B. (2001). Child growth in the time of drought. Oxford Bulletin of Economics and Statistics, 63(10), 29-36.

International Labour Organization (ILO). (2011). Social protection floor for a Fair and inclusive globalization Report of the Advisory Group chaired by Michelle Bachelet. Geneva: ILO.

Lund, F. (2002). Crowding In Care, Security, and Micro-Enterprise Formation: Revisiting the Role of the State in Poverty Reduction and Development. Journal of International Development, 14, 68 - 694.

Makiwane, M. \& Kwizera, S. (2006). An investigation of quality of life of the elderly in South Africa, with specific reference to Mpumalanga province. Applied research in Quality of life, 1, 297-313 Available at https://www.statssa.gov.za/Publications/Report-03- 19-00/Report- (Accessed March 16, 2013).

Miller, C. M., Tsoka, M. \& Reichert, K. (2011). The impact of the social cash transfer scheme on food security in Malawi. Food Policy, 36, 230-238.

MCDSS/GTZ. (2007). The pilot social cash transfer scheme in Zambia: summary report (6 ${ }^{\text {th }}$ Ed).Lusaka: MCDSS. [Online] Available: http://mcdss.websitedesign.co.zm/media/17.sct_summary_report_6th_.pdf (March 07, 2012).

National Treasury. (2003). Intergovernmental Fiscal Review National Treasury, Republic of South Africa. Available at http://www.treasury.gov.za/publications/igfr/2003/title.pdf (Accessed March 16, 2013).

Ncube, N., Tanga, P. T. \& Bhumira, B. (2014). The impact of deagrarianisation on the socio-economic wellbeing of rural inhabitants in South Africa.

Ngqushwa Local Municipality. (2012). Annual Report 2011/2012 [Online] Available: http://mfma.treasury.gov.za/Documents/06.\%20Annual\%20Reports/201112/02.20Local\%20 municipalities/EC126\%20Ngqushwa/EC126\%20Nqgushwa\%20Annual\%20Report\%20201112.pdf (May 13, 2013).

Republic of South Africa (RSA). (1996). Constitution of the Republic of South Africa, No 108 of 1996. Pretoria: Government Printers.

Siebrits, K., Armstrong, P. \& Lekezwa, B. (2008). Poverty in South Africa: A profile based on recent household surveys. Economic Working Papers 04. Stellenbosch: University of Stellenbosch, Department of Economics.

Social Research Centre. (2008). Introducing Empowering Conditional Cash Transfers to Egypt: The Ain elSira Experiment. America: University of Cairo.

South African Social Security Agency (SASSA). (2012). Annual statistical report on social grants: 2010/11 report: South Africa: Pretoria. [Online] Available: www.sassa.gov.za(April 06/04/2012).

South African Social Security Agency (SASSA). (2013). Annual statistical report on social grants. [Online] Available: www.sassa.gov.za (March 13, 2013).

Southern Africa Labour and Development Research Unit. (2010). National Income Dynamics Study 20102011. Wave 2 (dataset): Version 1.Cape Town: Southern Africa Labour and Development Research Unit.

Statistics South Africa. (2011). South African Statistics 2011. [Online] Available: http://www.statssa.gov.za/publications/SAStatistics/SAStatistics2011.pdf (May 10, 2013). 
Statistics South Africa. (2012). Poverty profile of South Africa. Application of the poverty lines on the Living Conditions Survey 2008/2009. [Online] Available: www.statssa.gov.za (July 10, 2013).

Tanga, P. T. (2007). Social grants and the fight against poverty in South Africa. Lesotho Social Sciences Review, 11(1\&2), 1-20.

Tanga, P. T. \& Gutura, P. (2013a). The impact of Old Age Grant on Rural Eastern Cape. Mediterranean Journal of Social Sciences, 3(13), 625-635.

Tanga, P. T. \& Gutura, P. (2013b). Paternal involvement in the financial welfare of children receiving child support grant in South Africa. Pakistan Journal of Social Sciences, 10(5), 190-197.

Tanga, P. T. \& Tangwe, M. N. (2014). The perceived impact of the economic crisis on social grant recipients in the Eastern Cape, South Africa. Mediterranean Journal of Social Sciences, 5(2), 277287.

Van der Berg, S., Siebrits, K. \& Lekezwa, B. (2010). Efficiency and equity effects of social grants in South Africa, Working Papers. 15/2010. Stellenbosch: Stellenbosch University, Department of Economics.

Veras, F., Ribas, R. \& Osorio, R. (2007). Evaluating the Impact of Brazil's Bolsa Família: Cash Transfer Programmes in Comparative Perspective. Evaluation Note 1, International Poverty Centre (IPC). Brasilia: IPC. 